\title{
Field Trials with a New Genetically Engineered Vaccine for Protection Against Progressive Atrophic Rhinitis in Pigs
}

\author{
By A. Bording, ${ }^{1,2}$ K. Nymark ${ }^{2}$ and E. Smidt ${ }^{2}$ \\ ${ }^{1}$ Department of Animal Science and Animal Health, Royal Veterinary and Agricultural Unıversity, Copenha- \\ gen, and ${ }^{2}$ Intervet Scandınavia AS, Copenhagen, Denmark.
}

\begin{abstract}
Bording, A., K. Nymark, E. Smidt: Field trials with a new genetically engineered vaccine for protection against progressive atrophic rhinitis in pigs. Acta vet. scand. 1994, 35, 155-163. - Field trials were carried out testing a new genetically engineered vaccine agannst Progressive Atrophic Rhinitis. The vaccine contained a non-toxic recombinant derivative of the $P$. multocida toxin. The experimental vaccine was compared with a commercial vaccine in 4 farms and in 1 farm 2 different dose regimens were applied. A total of 825 sows were included. The primary efficacy varıable was a comparison of post mortem evaluation of the degree of conchae atrophy in the 4585 pigs. The pigs were slaughtered at normal slaughter weight. The secondary efficacy variables were serological response and age at slaughter. In all farms the experımental vaccine provided significantly better protection of the progeny than the control vaccine. The serological response in sows was significantly higher in all farms than the response to the control vaccine. The serological response did not differ between farms.
\end{abstract}

vaccination; Pasteurella multocida; toxin; derivative.

\section{Introduction}

The primary cause of Progressive Atrophic Rhinitis (PAR) in pigs is the toxin (PMT) produced by some strains of the bacterium Pasteurella multocida (de Jong et al. 1980, Pedersen et al. 1988). The disease causes atrophy of the nasal conchae and growth retardation in more severe cases (Barfod \& Pedersen 1984). Several vaccines against Atrophic Rhinitis are available on the market. The vaccines containing the detoxified PMT and either cells of Bordetella bronchiseptica or Pasteurella multocida or both are generally considered the most effective (Barfod \& Pedersen 1984, Voets 1988, Pejzak et al. 1991).

Experimental studies have shown that vaccination of sows with vaccines solely containing the detoxified, purified PMT is effective in providing colostral immunity to the progeny against PAR (Foged et al. 1989, Nielsen et al. 1991).

The vaccine used in the present study is a single component vaccine containing a non-toxic but highly immunogenic protein, the dO-protein, as the antigen. The dO-protein was produced through deletion of 121 amino acids in the N-terminal end of the native PMT (Petersen et al. 1991).

The present paper describes 5 field trials performed with this new vaccine. The field trials were all carried out in commercial farrow-tofinish herds in the period from October 1990 till December 1991. 


\section{Material and methods \\ Experimental vaccine}

The dO-protein was produced in E. coli $\mathrm{k} 12$ as described earlier (Petersen et al. 1991). The $\mathrm{dO}$-protein was purified by $\left(\mathrm{NH}_{4}\right)_{2} \mathrm{SO}_{4}$ precipitation from a crude extract of the $E$. coli pSPE 857.The dO-protein was estimated at $50 \%$ purity by SDS-PAGE. The quantification was done by using a sandwich ELISA as described by Foged (1988). The antigen was stored at $-20^{\circ} \mathrm{C}$.

Purified dO-protein was adsorbed to a $20 \%$ Alhydrogel suspension (Alhydrogel, grade A, Superfos, Denmark) according to the guidelines given by the manufacturer. The vaccines were diluted into concentrations of 5 or $10 \mu \mathrm{g}$ of antigen per ml using phosphate buffered saline and $\mathrm{pH}$ was installed at 7.5-7.6 by means of a pH-meter (RADIOMETER, $\mathrm{pH}$ M82, Denmark). Finally thiomersal $(0.02 \%$ $\mathrm{w} / \mathrm{v}$ ) was added as a preservative. The vaccine (PrO-Tech-AR) was stored at $4^{\circ} \mathrm{C}$.

\section{Control vaccine}

A commercial vaccine against Atrophic Rhinitis $^{1}$ was used as a positive control. One $\mathrm{ml}$ of the vaccine was composed as follows: 1) $10^{9}$ killed $P$. multocida cells of a toxin producing strain; 2) $10^{9}$ killed $B$. bronchiseptica cells; 3 ) formaldehyde treated toxoid of the $P$. multocida toxin, 10,000 Multoxin Units (1.5 $\mu \mathrm{g}$ PMT). The vaccine was adjuvanted with Alhydrogel.

\section{Serological test}

Serum samples obtained during the trials were tested for the presence of anti-PMT antibodies by the ELISA previously described (Foged 1988, Foged et al. 1990). A serum sample was considered sero-positive when the serum blocked the binding of PMT to the

\footnotetext{
${ }^{1}$ Atrinord $^{\circledR}$ Vet.
}

coating MAb, so that the absorbance was reduced to less than $50 \%$ of the absorbance obtained when buffer was used instead of serum. For each sero-positive sample, the $50 \%$ blocking titer to PMT was estimated by using threefold dilutions and interpolation on a semi-logarithmic plot of absorbance (linear scale) versus dilution factor (logarithmic scale).

\section{Description of farms}

All 5 farms included in this study were commercial farrow-to-finish herds holding 100500 breeding animals. PAR had been the major problem in the farms for several years. Various programmes (vaccination with Atrinord $^{\circledR}$ Vet., medication, change of management and environmental factors) had been implemented in the farms over the years but with no significant benefit.

\section{Trial design}

The design of the trial is summarized in Table 1. All sows were vaccinated twice at 2 weeks interval. The vaccinations were done 68 weeks prior to farrowing and 2-3 weeks prior to farrowing. In 4 of the farms a number of the sows in both the control group and in the experimental group were bled at the time of farrowing. The blood samples were analyzed for the presence of anti-PMT antibodies in the ELISA test previously described. In 2 farms a number of pigs were bled at the age of 5-7 weeks. All trials were started in November 1990 and completed in December 1991. A total of 825 sows and 4585 pigs were included in the trial.

\section{Randomisation and blinding}

In farm no. 1

the sows were allocated to one of the 2 treatment groups by randomisation. The sow lists were used for this purpose. The randomisation was done by drawing a random number; 
Table 1. Summary of trial design.

\begin{tabular}{|c|c|c|c|c|c|c|}
\hline \multirow{2}{*}{ Farm } & \multirow{2}{*}{ Sows in trial } & \multirow{2}{*}{ Trial groups } & \multicolumn{4}{|c|}{ Efficacy varıables } \\
\hline & & & Serology & PAR* & PAR** & Age at slaughter \\
\hline \multirow[t]{2}{*}{1} & 51 & $\begin{array}{c}\text { PrO-Tech-AR } \\
(10 \mu \mathrm{g})\end{array}$ & sows \& pigs & + & + & + \\
\hline & 44 & Control \# & sows \& pigs & + & + & + \\
\hline \multirow[t]{2}{*}{2} & 65 & $\begin{array}{c}\text { PrO-Tech-AR } \\
(10 \mu \mathrm{g})\end{array}$ & sows \& pigs & + & + & nd» \\
\hline & 65 & $\begin{array}{c}\text { PrO-Tech-AR } \\
(5 \mu \mathrm{g})\end{array}$ & sows \& pigs & + & + & nd \\
\hline \multirow[t]{2}{*}{3} & 200 & $\begin{array}{c}\text { PrO-Tech-AR } \\
(10 \mu \mathrm{g})\end{array}$ & sows & + & + & nd \\
\hline & 200 & Control \# & sows & + & + & nd \\
\hline \multirow[t]{2}{*}{4} & 40 & $\begin{array}{l}\text { PrO-Tech-Ar } \\
\quad(10 \mu \mathrm{g})\end{array}$ & nd & + & + & nd \\
\hline & 40 & Control \# & nd & + & + & nd \\
\hline \multirow[t]{2}{*}{5} & 60 & $\begin{array}{c}\text { PrO-Tech-AR } \\
(10 \mu \mathrm{g})\end{array}$ & sows & + & + & nd \\
\hline & 60 & Control \# & sows & + & + & nd \\
\hline
\end{tabular}

*PAR $=$ frequency of clinical PAR.

$* *$ PAR $=$ post mortem evaluation of the nasal conchae on snout cross sections.

\#Control $=$ in the control groups marked the commercial vaccine against Atrophic Rhinitis was used.

»nd $=$ not done.

the sow with this chronological number was located on the sow list; a second random number was drawn; allocation to either of the vaccine groups was done by counting through the sow list, and every second time the number was reached the sow was allocated to the experimental group and every second time to the control group. In farms numbers 2, 3, 4, and 5 sows were assigned to treatment as follows: All sows with uneven sow numbers were allocated to the control group, and all sows with even numbers were allocated to the experimental group.

The evaluation of the snout cross sections post mortem was performed blindly in farm no. 1: After the scoring of each snout, the code on the snout was broken. Till then it was not known to the veterinarian scoring the snouts, which vaccine group the particular snout belonged to. In farms numbers $2,3,4$, and 5 the snouts were scored openly by 2 veterinarians. In case of disagreement, the highest score was considered the score.

\section{Nasal swabs}

Nasal swabs were taken from 8 piglets 5 weeks old and 8 piglets 8 weeks old in each farm before the start of the trials. Toxigenic $P$. multocida were found in all 5 farms.

\section{Conchae changes}

The degree of atrophy of the conchae was basically evaluated according to the scale of Bendixen (1971). This scale has 5 scores ranging from 0 to +++ . However, in the present studies the 2 lowest scores $(0, ?)$ were com- 
Table 2. Clinical PAR before and after the trial period.

\begin{tabular}{lcrc}
\hline \multirow{2}{*}{ Farm } & Before start of trial & \multicolumn{2}{c}{ At the end of trial } \\
\cline { 3 - 4 } & & Control & Experiment \\
\hline 1 & $15 \%$ & $23 \%$ & $7 \%$ \\
$2^{*}$ & $40 \%$ & $1 \%$ & $1 \%$ \\
3 & $20 \%$ & $1 \%$ & $1 \%$ \\
4 & $10 \%$ & $1 \%$ & $1 \%$ \\
5 & $25 \%$ & $10 \%$ & $2 \%$ \\
\hline
\end{tabular}

* In this farm the control group received a lower dose of the experimental vaccine and not the commercial vaccine used in the rest of the farms.

bined into 1 group. Thus the atrophy of the conchae was scored on a 4 rank scale. Each half of the snout was scored separately. The snout was given 1 score (the highest of the 2 halves). For calculating the mean snout score for each litter the 0 to +++ scale was converted into a numeric scale as follows: no changes $=0$, grade $=0 \&$ biological variation $=$ ?, grade $=1$; slight changes $=+$, grade $=2$; severe atrophy $=++$, grade $=3$; total atrophy $=$ +++ grade $=4$. In this grading scale system a pig could have the score from $0(2 \times 0)$ to 8 (2×4).

\section{Statistical methods}

All data on snout cross sections were analysed in $\chi^{2}$ test and in a non-parametric analysis of variance (Kruskall Wallis). The distribution of the snout scores in the farms was analysed in the Cochran Mantel-Haenzel test. The serological data were analysed either in an unpaired t-test or in one-way or two-way ANOVA. Regression analysis was used when analysing the factors influencing the age at slaughter. The significance level was chosen at the $5 \%$ level and all tests are presented as two-tailed.

All statistical analyses were done using the SAS programmes (SAS Institute Inc. 1987).
Table 3. Distribution of degree of conchae atrophy in pigs not included in the trial.

\begin{tabular}{lcrrrr}
\hline & \multirow{2}{*}{ No of } & \multicolumn{5}{c}{ Score } \\
\cline { 3 - 6 } & plgs & \multicolumn{1}{c}{0} & + & ++ & +++ \\
\hline 1 & 58 & $8 \%$ & $12 \%$ & $29 \%$ & $50 \%$ \\
2 & 26 & $15 \%$ & $15 \%$ & $19 \%$ & $50 \%$ \\
3 & 43 & $0 \%$ & $30 \%$ & $37 \%$ & $33 \%$ \\
4 & 48 & $2 \%$ & $21 \%$ & $21 \%$ & $56 \%$ \\
5 & 59 & $5 \%$ & $25 \%$ & $46 \%$ & $24 \%$ \\
\hline
\end{tabular}

\section{Results}

Before the start and at the end of each trial an estimate of the frequency of clinical PAR was done. The approximate percentages observed are listed in Table 2.

In all 5 farms snouts were collected at the abattoir from pigs not included in the field trial. These snouts were collected a few weeks before slaughtering of the experimental pigs began. The snouts were evaluated for conchae atrophy. These were meant to provide a momentary impression of the degree of conchae atrophy present in the pigs born just before the clinical trials started. The distribution of the conchae atrophy in each of the 5 farms is shown in Table 3. As it appears the frequency of severe conchae atrophy $(+++)$ in these pigs not included in the trial was between $24 \%$ and $56 \%$.

A total of 4585 snouts were collected at the abattoir from pigs included in the trials. 2464 were from pigs born from sows vaccinated with the experimental vaccine and 2111 were from pigs born from sows vaccinated with the control vaccine. The results from the evaluation of the conchae atrophy on snout cross sections are shown in Tables 4 and 5.

As appears from the tables the number of pigs with severe conchae atrophy is higher in the 
control pigs than in the pigs vaccinated with the experimental vaccine. The differences were statistically significant in all of the farms when tested for equal distribution in a Kruskall Wallis test (farm 1, 3, 5, p <0.001 and farm $4 \mathrm{p}=0.013$ ).

The results of the analyses of serum for antiPMT antibodies in sows are shown in Table 6. The titers in the control groups and in experimental groups in each farm were compared in an unpaired $t$-test, and in all of the 3 farms the experimental sows developed significantly higher anti-PMT antibodies than the sows in the control groups. The titers from the sows in all farms in the control groups and in the experimental groups respectively were compared in an analysis of variance and there was found no significant difference in the mean titer level between the farms within any of the 2 vaccination groups $\left(\mathrm{p}_{\exp }=0.35\right.$ and $\mathrm{p}_{\text {con }}=$ 0.39 ).

In 2 farms a number of pigs were bled at the age of 5-7 weeks. The results from these blood samples are displayed in Table 7.

In 1 farm (no.1) the age at slaughter was recorded for each pig and calculated for each litter. The mean ages at slaughter and snout
Table 4. Distribution of the degree of conchae atrophy in pigs born from sows vaccinated with the commercial control vaccine.

\begin{tabular}{lcrrrr}
\hline \multirow{2}{*}{ Farm } & \multirow{2}{*}{$\begin{array}{c}\text { No of } \\
\text { pigs }\end{array}$} & \multicolumn{5}{c}{ Score } \\
\cline { 3 - 6 } & & 0 & + & ++ & +++ \\
\hline 1 & 363 & $34 \%$ & $24 \%$ & $23 \%$ & $20 \%$ \\
3 & 912 & $10 \%$ & $34 \%$ & $36 \%$ & $20 \%$ \\
4 & 295 & $22 \%$ & $37 \%$ & $37 \%$ & $13 \%$ \\
5 & 541 & $6 \%$ & $20 \%$ & $40 \%$ & $33 \%$ \\
\hline
\end{tabular}

Table 5. Distribution of the degree of conchae atrophy in pigs born from sows vaccinated with the experimental vaccine.

\begin{tabular}{llccrc}
\hline \multirow{2}{*}{ Farm } & \multirow{2}{*}{$\begin{array}{c}\text { No of } \\
\text { pigs }\end{array}$} & \multicolumn{4}{c}{ Score } \\
\cline { 3 - 6 } & & 0 & + & ++ & +++ \\
\hline 1 & 393 & $43 \%$ & $23 \%$ & $24 \%$ & $9 \%$ \\
2 & $575 *$ & $58 \%$ & $34 \%$ & $5 \%$ & $1 \%$ \\
3 & 834 & $21 \%$ & $48 \%$ & $26 \%$ & $5 \%$ \\
4 & 258 & $29 \%$ & $42 \%$ & $28 \%$ & $1 \%$ \\
5 & 404 & $15 \%$ & $41 \%$ & $36 \%$ & $8 \%$ \\
\hline
\end{tabular}

* The sows in farm 2 were all vaccinated with the PrO-Tech-AR vaccine, but 2 different doses were used. As there was found no statistical difference in the distribution of the snout scores between the 2 groups $\left(\chi^{2}=5.78, p=0.123\right.$; Kruskall Wallıs $\left.\chi^{2}=2.42, p=0.120\right)$, the higher and lower dose groups were combined into 1 group.

Table 6. Serological response in sows to vaccination.

\begin{tabular}{|c|c|c|c|c|c|}
\hline Farm & No of sows & Vaccine & $x$ & SD & SE \\
\hline 1 & $\begin{array}{l}29 \\
29\end{array}$ & $\begin{array}{c}\text { control } \\
\text { experiment. }\end{array}$ & $\begin{array}{r}40.4 \\
109.1\end{array}$ & $\begin{array}{r}83.1 \\
1343\end{array}$ & $\begin{array}{l}15.4 \\
24.9\end{array}$ \\
\hline $\begin{array}{l}2^{*} \\
2 * *\end{array}$ & $\begin{array}{l}16 \\
18\end{array}$ & $\begin{array}{l}\text { experiment. } \\
\text { experiment. }\end{array}$ & $\begin{array}{l}86.4 \\
81.6\end{array}$ & $\begin{array}{r}112.1 \\
97.4\end{array}$ & $\begin{array}{l}28.0 \\
18.7\end{array}$ \\
\hline 3 & $\begin{array}{l}10 \\
14\end{array}$ & $\begin{array}{c}\text { control } \\
\text { experiment. }\end{array}$ & $\begin{array}{r}11.9 \\
115.5\end{array}$ & $\begin{array}{r}14.7 \\
112.9\end{array}$ & $\begin{array}{r}4.6 \\
30.2\end{array}$ \\
\hline 5 & $\begin{array}{r}12 \\
9\end{array}$ & $\begin{array}{c}\text { control } \\
\text { experiment. }\end{array}$ & $\begin{array}{r}7.3 \\
94.9\end{array}$ & $\begin{array}{r}7.8 \\
110.8\end{array}$ & $\begin{array}{r}2.2 \\
36.9\end{array}$ \\
\hline
\end{tabular}

* In this farm all sows were vaccinated with the experimental vaccine, only 2 different doses were used. The sows in this group were vaccinated with $25 \mu \mathrm{g}$ of antıgen per dose.

** The sows in this group were vaccinated with $50 \mu \mathrm{g}$ of antigen per dose. 
Table 7. Ant1-PMT titres in 5-7 weeks old pigs born from vaccinated sows.

\begin{tabular}{lccrrr}
\hline Farm & No of litters & Vaccine & $\overline{\mathbf{x}}$ & SD & Age \\
\hline 1 & 79 & control & 3.3 & 3.7 & 7 weeks \\
& 88 & experıment. & 4.7 & 4.1 & 7 weeks \\
$2 *$ & 18 & experıment. & 35.5 & 59.7 & 5 weeks \\
& 18 & experıment. & 25.5 & 31.5 & 5 weeks \\
\hline
\end{tabular}

* In farm no. 2 all sows were vaccinated with the experımental vaccine, only 2 different doses were used.

Table 8 . Distribution of the mean age at slaughter on the mean snout scores for the litters.

\begin{tabular}{|c|c|c|c|c|}
\hline & \multicolumn{4}{|c|}{ Interval mean snout score of the litter } \\
\hline & $\begin{array}{c}0, ? \\
(0-24) \#\end{array}$ & $\begin{array}{c}+ \\
(2.5-4.4)\end{array}$ & $\begin{array}{c}++ \\
(4.5-6.4)\end{array}$ & $\begin{array}{c}+++ \\
(6.5-80)\end{array}$ \\
\hline Control & $181(5)^{*}$ & $187(13)$ & 201(27) & $214(2)$ \\
\hline No of litters & 4 & 23 & 14 & 3 \\
\hline PrO-Tech-AR & $186(10)$ & 181(13) & 191(7) & 217 \\
\hline No. of litters & 21 & 17 & 12 & 1 \\
\hline
\end{tabular}

Table 9. Mean values of serological response, snout score and age at slaughter in farm no 1.

\begin{tabular}{cccc}
\hline Vaccine & Mean titer (sd) & Mean score (sd) & Mean age (sd) \\
\hline Control $^{*}$ & $4.3(5.8)$ & $4.2(1.5)$ & $1914(20.4)$ \\
Experiment $^{* *}$ & $7.8(10.2)$ & $3.3(16)$ & $186.9(131)$ \\
\hline
\end{tabular}

* The number of litters included was 44 .

** The number of litters included was 51 ,

score intervals for both vaccination groups are shown in Table 8.

The mean values and standard deviations for the age at slaughter, the snout score and the serological response were calculated for each vaccination group. The results are shown in Table 9.

The influence of the vaccine, the snout score and the serological response on the age at slaughter of the pigs were analysed. There was found no change in the age at slaughter whether the pigs were born from sows vaccinated with the control vaccine or with the experimental vaccine $(p=0.42)$. The age at slaughter also was not associated with the titer of the piglets at 7 weeks of age $(p=0.54)$. As 
opposed to this the age at slaughter increased significantly when the mean score of the litter increased $(p=0.0011)$.

\section{Discussion}

Previous studies of the efficiency of single component vaccines against PAR have reported successful results. One experimental study described good protection of the progeny when the sows were vaccinated with a formaldehyde detoxified affinity purified $P$. multocida toxin (Foged et al. 1989). Another experimental study described similar good protection of the progeny when the sows were vaccinated with the recombinant dO-protein (Nielsen et al. 1991). The same dO-protein was used in the experimental vaccine used in the present trials.

The present studies for the first time describe the use of a single component vaccine for protection against PAR under field conditions. The experimental vaccine was compared to a commercial vaccine composed in the way presently considered the optimal, as it contained Pm-toxoid (Barfod \& Petersen 1984, Voets 1988, Kobisch \& Pennings 1989). In 1 farm (number 1) additional tetracycline treatment was provided to the control piglets. In all the farms the experimental vaccine performed significantly better than the control vaccine. The sows developed significantly higher titers and the titers of the piglets were accordingly high.

In 1 farm (number 2) all breeding animals were vaccinated with the experimental vaccine. In this farm the sows were vaccinated with either $25 \mu \mathrm{g}$ or $50 \mu \mathrm{g}$ of antigen at each vaccination. The protection provided from the 2 dosages was not significantly different, and it was in this farm the best results were obtained from the experimental vaccine. The frequency of severe conchae atrophy was reduced from $50 \%$ to $1 \%$.
The results in this farm may reflect one of the difficulties in interpreting results from field trials with vaccines. When a parallel control group is included the herd immunity will not become as homogeneous and the infection pressure may be kept at a higher level.

The serological response in the sows vaccinated with the experimental vaccine was at the same level as the response obtained in an experimental study performed with a similar vaccine (Nielsen et al. 1991). In all farms the serological response was significantly higher in the experimental group than in the control group. The titers obtained did not differ between the farms. Thus one may expect a homogeneous response between herds.

However, in the present study there was found no significant association between the titer of the parent sow at farrowing and the snout score of the litter, neither in the experimental group nor in the control group. In the study described earlier by Nielsen et al. (1991) a highly significant correlation $\left(\mathrm{r}^{2}=0.89\right)$ between these two variables was found. The lack of correlation in the field studies could be explained by two factors.

First the scoring of the conchae atrophy in the present studies was done by a subjective discontinuous rank scale, and was as such nonparametric. The scoring in the experimental study by Nielsen et al. (1991) was done by using a continuous scale (the turbinate perimeter ratio). The use of an objective continuous variable allows a more detailed analysis of the data and provides a much more objective information (Bäckström \& Collins 1988, Barfod et al. 1990, Sørensen et al. 1990). The method, however, requires more time and personnel than simple rank scoring.

Second the calculations of the correlation between conchae score and serological response in the experimental study were based on blood samples from 1 week old piglets, where- 
as the piglets in the field trials were 5-7 weeks old when bled. Studies of the decline of the colostral immunity after vaccination against Atrophic Rhinitis (Foged et al. 1989, Kobish \& Pennings 1989) have shown a significant decrease in circulation PMT-antibodies in the piglets from the 1st week of life till the 12th. Thus the lack of significant correlation between titers and conchae score in the present studies could also be explained by the relatively late age of bleeding. Unfortunately practical circumstances made it impossible to obtain blood samples at an earlier age.

A significant increase in the age at slaughter concurrently with increasing degrees of conchae atrophy $(++/+++)$ was observed for both vaccination groups. This has been reported in earlier studies (Barfod \& Petersen 1984, Sørensen et al. 1990). This increase in age tended to be most evident in the control group. Also the deviation of the age at slaughter within each litter was more pronounced in the control litters than in the experimental litters.

The experimental vaccine performed significantly better than the control vaccine in all the farms. However, there was some variation in the final result between the farms as regards the snout scoring whereas the serological responses in the sows did not differ significantly between farms. This could support the theories that the development of PAR is an interaction between immune status and infection, environment, and management (Schoss et al. 1988, Nielsen 1988).

\section{Acknowledgements}

The authors wish to thank the veterınarians and the farmers and the slaughter houses makıng these field trials possible. The superb assistance provided by the technicians Anders Wamsler and Lis W. Johannsen is greatly appreciated.

\section{References}

Barfod $K$, Pedersen $K B$ : Influence of vaccination of sows with Bordetella-Pasteurella vaccines on occurrence of atrophic rhinitis among their offspring after experimental infectıon with Bordetella bronchiseptica and toxigenic Pasteurella multocıda. Nord. Vet. Med. 1984, 36, 337-345.

Barfod K, Sørensen V, Nielsen JP: Methods of evaluation of the degree of atrophic rhinitis. Proc. 11th IPVS Congr Lausanne. 1990, p 70.

Bendlxen HC: Om Nysesyge hos svinet. (Chronic dystrophic s. atrophic s. infectious rhinitis in pigs). Nord. Vet. Med. 1971, 23 (suppl I).

Collıns MT, Backstom LR, Brim TA - Turbinate perimeter ratio as an indicator of conchal atrophy for diagnosis of atrophic rhinitis in pigs Amer. J. vet. Res. 1989, 50, 421-424.

de Jong MF, Oie HL, Tetenburg BJ: AR-pathogen-city-tests for Pasteurella multocida isolates. Proc 6th IPVS Congr., Copenhagen. 1980, p 211.

Foged NT: Quantification and purification of Pasteurella multocida toxin by using monoclonal ant1bodies. Infect. Immun. 1988, 56, 1901-1906.

Foged NT, Nielsen JP, Barfod K: The use of ELISAdetermination for Pasteurella multocida toxın antibodies in control of progressive atrophic thinitis Proc. 11th IPVS Congr. Lausanne. 1990, p 49.

Foged NT, Nielsen JP, Pedersen KB· Differentiation of toxigenic from nontoxigenic isolates of Pasteurella multocida by enxyme-linked immunosorbent assay. J. clin. Microbiol. 1988, 26, 14191420.

Kobisch M, Pennings A: An evaluation in pigs of Nobi-Vac AR and an experimental atrophic rhinitıs vaccine containing $P$. multocıda DNTtoxoid and B bronchiseptica. Vet. Rec. 1989, 124, 57-61.

Martın SW, Meek AH, Willeberg P. Veterınary Epidemiology, Principles and methods. Iowa State University Press, Ames. 1987, 343 pp.

Matthews DE, Farewell WT: Using and understanding medical statistics. Karger, 1988, 185 pp.

Nielsen JP. Pasteurella Nysesyge. Ep1demılog1, d1- 
agnostik og eksperimentelle undersøgelser. L1centıat afhandling (Pasteurella atrophic rhınitis in pıgs: Epidemiology, diagnostic and experimental investigations). Ph.D. Thesis. Nat.Vet. Lab. and Royal Vet. Agricult. Unıv., Copenhagen.

Nielsen JP, Foged NT, Sørensen V, Barfod K, Bording $A$, Petersen $S K$ : Vaccination against progressive atrophic rhinitss with a recombinant Pasteurella multocida toxin derivative. Can. J. vet. Res. 1991, 55, 128-138.

Pedersen KB. Nielsen JP, Foged NT, Elling F, Nielsen $N C$, Willeberg $P$ : Atrophic rhinitis in pigs: Proposal for a revised definition. Vet. Rec. 1988, 122, 190-191.

Pejsak Z, Hogg A, Wasınska B, Foreman K: Comparison of 6 different regimens for the control of atrophic rhinitis in swine. J. vet. Med. B. 1990, 37, 593-598.

Petersen SK, Foged NT, Bording A, Nielsen JP, Riemann $H K$, Frandsen PL: Development of a recombınant vaccine against progressive atrophic rhinitis in pigs. Infect. Immun. 1991, 59, 1387 1393.

SAS Institute Inc.: SAS/STAT guide for personal computer. SAS Institute, Cary, N.C. 1987.

Schoss P: Neues uber die Rhinitis atrophicans des Schweines. Wien. Tierarztl. Mschr. 1987, 74, 301305.

Sørensen V, Barfod K, Nielsen JP, Foged NT: Effect of atrophy and serum antitoxin titer on the daily weight gain and feed conversion. Proc. 11th IPVS Congr. Lausanne. 1980. p 57.

Voets $M T$. Challenge experiments to test the protective effect of AR-vaccines. Proc. 10th IPVS Congr. Rio de Janeiro. 1988, p 42.

\begin{abstract}
Sammendrag
Klınisk afprøvning med gen-splejset vaccine mod nysesyge (PAR) hos svin
\end{abstract}

Der er blevet udført klıniske afprøvnınger med en ny, gensplejset vaccine mod nysesyge (progressiv atrofisk rhinitis). Vaccinen indeholdt et ikke toksisk derivat af Pasteurella multocida toksinet. Derivatet var oprenset ved saltfældning før tilblanding tıl vaccinen. Den eksperımentelle vaccıne blev sammenlıgnet med en kommercielt tılgængelig toxoid vaccine mod atrofisk rhinitis i 4 besætninger. I én besætning blev den eksperimentelle vaccine anvendt med to forskellige doseringer. I alt indgik der 1 unders $\varnothing$ gelserne 826 søer og deres kuld fra 5 forskellige so- og slagtesvinebesætninger. Søerne 1 begge fors $\emptyset$ gsgrupper blev vaccineret to gange, 6-8 og 2-3 uger før faring. Vaccınernes effektıvitet blev prımært vurderet ved, at der efter grisenes slagtning ved normal slagtevægt blev foretaget en sammenligning af graden af atrofi af næsehulens conchae hos 4.575 grise. Sekundært blev effekten vurderet ud fra søernes serologiske respons og grisenes alder ved slagtning. I alle besætningerne ydede den eksperimentelle vaccine bedre beskyttelse af grisene end kontrolvaccinen. Det serologiske respons 1 søerne var signifikant højere $\mathrm{i}$ alle besætnınger end responset mod kontrolvaccinen Det serologiske respons mod den eksperimentelle vaccine var ens $\mathrm{i}$ de forskellige besætninger. I én besætnıng blev grisenes alder ved slagtnıng beregnet. Grise født af søer, der var vaccineret med den eksperımentelle vaccine, nåede slagtevægten ca. 5 dage hurtigere end grıse i den kontrolvaccinerede gruppe.

(Recelved July 19, 1993; accepted February 21, 1994).

Reprints may be requested from: Intervet Scandinavia AS, 5 Rønnegade, DK-2100 Copenhagen $\emptyset$, Denmark. 
